\title{
EXPLORATORY FAVORABILITY CLASSIFICATION USING WEIGHTS OF EVIDENCE: A CASE STUDY IN SERGIPE-ALAGOAS BASIN, BRAZIL
}

\author{
Bernardo Faria de Almeida ${ }^{1}$, Renato Lopes Silveira ${ }^{1}$, \\ Elaine Maria Lopes Loureiro ${ }^{1}$ and Edilson Fernandes de Arruda $^{2}$
}

\begin{abstract}
This article discusses the importance of the favorability evaluation, proposed in data-driven mineral potential maps (MPM), for decision-making in exploratory activities of petroleum and natural gas. We consider geophysical and geological information as evidences that define the essential elements of a petroleum system. We assess such evidences by means of weights of evidence methodology, which makes use of data coming from hydrocarbon discovering wells. We apply the proposed assessment in a case study in Sergipe-Alagoas and employ the results to classify areas of interest in different favorability levels.
\end{abstract}

Keywords: petroleum systems, favorability maps, mineral potential maps, Sergipe-Alagoas basin.

RESUMO. Este artigo discute a importância da avaliação de favorabilidades propostas em mapas de potencial mineral, baseados em dados (data-driven), para as tomadas de decisões em atividades exploratórias de petróleo e gás natural. Nós consideramos as informações geológicas e geofísicas como evidências que definem os elementos essenciais de um sistema petrolífero. Avaliamos as evidências através da metodologia de pesos de evidências (weights of evidence), a qual faz uso de dados obtidos a partir de poços descobridores de hidrocarbonetos. Aplicamos a avaliação proposta em um estudo de caso na bacia de Sergipe-Alagoas e empregamos os resultados obtidos para classificar a área de interesse em diferentes níveis de favorabilidade.

Palavras-chave: sistemas petrolíferos, mapas de favorabilidade, mapas de potencial mineral, bacia de Sergipe-Alagoas.

\footnotetext{
${ }_{1}^{1}$ Agência Nacional do Petróleo, Gás Natural e Biocombustíveis - ANP, Avenida Rio Branco, 65, Centro, 20090-004Rio de Janeiro, RJ, Brazil. Phone: +55 (21) 2112-8100

- E-mails: bfalmeida@anp.gov.br; rlsilveira@anp.gov.br; eloureiro@anp.gov.br

2Universidade Federal do Rio de Janeiro, Instituto Alberto Luiz Coimbra de Pós-Graduação e Pesquisa de Engenharia, Programa de Engenharia de Produção, Av. Athos da Silveira Ramos, 149, Bloco F, Sala 103, Centro de Tecnologia, Cidade Universitária, Ilha do Fundão, Mailbox 68507, 21941-972 Rio de Janeiro, RJ, Brazil. Phone: +55(21) 3938-8255 - E-mail: efarruda@po.coppe.ufrj.br
} 


\section{INTRODUCTION}

The use of geophysical methods is very important for petroleum system evaluation during exploratory activity. The information acquired from the available data regarding the area under analysis is critical for the decisions made in the exploration, and the acquisition of new data may produce a relevant cost in exploratory investments that have a high-risk exposure.

Despite the consensus that more data always contributes to reduce uncertainties, exploratory data typically provides imperfect information which drive the decision-making process (Sato et al., 2013; Rostirolla, 1997). Such information can be furnished by mineral-potential maps (MPM), which strive to spatially indicate more favorable regions to survey for mineral deposits (BonhamCarter, 1994; Harris \& Pan 1999; Singer \& Kouda, 1999; Brown et al., 2000; Brown et al., 2003; Harris et al., 2003; Porwal et al., 2003, 2004; Agterberg \& Bonham-Carter, 2005; De Quadros et al., 2006; Abedi et al., 2012; Magalhães \& Souza Filho, 2012; Pazand et al., 2013).

The favorability quantification in mineral exploration can be subdivided in two types of models, according to the mechanism used to associate the hydrocarbon accumulations with selected geological factors (Pazand et al., 2013): (1) knowledge-driven models and (2) objective quantification based on data, depending on the availability of the data and on the exploratory stage of the area of interest.

Evaluation methods based on data (Newendorp, 1972; Bonham-Carter, 1994; Moon, 1998; Cheng \& Agterberg, 1999; Carranza \& Hale, 2001; Porwal et al., 2003; Carranza et al., 2008; Cassard et al., 2008) propose to establish, in an empiric manner, the relationship among factors observed on indirect evidences in geological, geophysical, and geochemical data and on the known accumulations. It is this relashionship that is used to assess the exploratory favorability in areas being surveyed. The favorability indices are obtained based on evidences spatially organized in maps, which analyze petroleum system factors selected from data acquired in the area of interest. The importance of each evidence is evaluated based on the results observed and consolidated in a favorability map for the area (Harris et al., 2001; Harris \& Pan, 1999). The MPM technique allows the integration of data from different knowledge areas (geology, geophysics, geochemistry, and well data), and, for this reason, it presents considerable importance in exploration (Porwal, 2006; Carranza, 2011).

The relevance of this work is associated to the lack of information and the need to expand the geophysical and geological data acquisition in the Brazilian sedimentary basins. After a long monopoly period in the Brazilian exploration and produc- tion (E\&P) sector, the enactment of the Petroleum Law established regulatory changes that favored the expansion of data acquisition activities in the Brazilian sedimentary basins, and in addition established the Brasil-Rounds with the purpose to expand investments in the sector. The areas to be offered are promoted with data acquisition by means of a Geologic and Geophysic Pluriannual Plan (Anp, 2014), developed to increase the knowledge about the potential of the Brazilian sedimentary basins, with surveys of geological and geophysical technical data.

Mineral resource evaluation depends on the data acquisition in regional surveys (Jordanov et al., 2006). Moreover, operational research represents an important tool that makes use of these data to support the scheduling of exploratory and additional data acquisition activities (Cobb, 1960). In this work, we apply weights of evidence based on model proposed by Bonham-Carter, Agterberg and Wright (1990) to produce exploratory favorability maps. We employ the proposed technique to a case study in the SergipeAlagoas basin, which presents aspects about the tectonostratigraphic evolution and its confirmed petroleum systems. The numerical experiments indicate that the proposed evidences are related to the results of successful exploratory wells, i.e. those with identified discoveries. Furthermore, the model allows a careful classification of the area according to its exploratory favorability, and can be used to support exploratory decisions, data acquisition and selection of prospective exploration areas. In a regional perspective, when there is a lack of data, the less favorable areas may be subject to surveys for data acquisition or area relinquishment, whereas the more favorable areas are naturally atractive for future bidding round offers.

This work is organized as follows: Section 2 - Methodology - proposes a weights-of-evidence model of exploratory favorability. Section 3 - Case Study - applies the proposed model for the Sergipe-Alagoas basin. Section 4 - Results - is comprised of the numerical experiments for the case study. Finally, Section 5 Conclusion - concludes the paper.

\section{METHODOLOGY}

The weights-of-evidence (WOFE) technique allows the identification of patterns, such as structural features and geophysical and geochemical anomalies (Bonham-Carter et al., 1990), to map mineral potential (Agterberg, 1992; Cheng, 2014; He et al., 2014). It was employed to search for gold (Bonham-Carter et al., 1988; Harris \& Pan, 1999; Brown et al., 2000; Carranza \& Hale, 2002; Cheng et al., 2007; Hronsky \& Groves, 2008; Carranza, 2011; Silva et al., 2012; Ford \& Hart, 2013), groundwater (Vidal et al., 2005; Nampak et al., 2014; Pourtaghi \& Pourghasemi, 2014), 
copper (Abedi et al., 2014; Wenhui et al., 2014) and iron (Sato et al., 2013; Zhang et al., 2013).

For petroleum and natural gas (P\&NG) exploration, the WOFE technique usage is based on the petroleum system concepts and on exploratory plays, with the purpose of reducing the exposure of data acquisition investments to the exploratory risk, using probability theory (Rostirolla et al., 2003). This method was also employed for rockslide evaluations (Blahut et al., 2013) and landslide susceptibility (Blahut et al., 2009; Regmi et al., 2014; Kouli et al., 2014), among others.

Consider an area of interest $t>0 \mathrm{~km}^{2}$, divided into grids (cells) of constant area $u>0 \mathrm{~km}^{2}$. Clearly, $T=t / u$ is the number of cells in the area. If the area presents $D$ number of cells with confirmed occurrences of reservoirs, the prior probability that a randomly selected cell presents an occurrence is defined as $P(O c)=D / T$. With regards to the considered evidences within the area of interest, the model calculates the number of cells $B_{j}$ found in each evidence map $J$, where this evidence is present; the number of cells where the evidence is not observed is expressed by the term $\overline{B_{j}}=T-B_{j}$.

The conditional probability of selecting a cell with a reservoir occurrence, given that $B_{j}$ cells presented evidence map $J$, is defined as $P\left(O c / B_{j}\right)=\frac{\left|B_{j} \cap O c\right|}{B_{j} \mid}$, where $|A|$ denotes the cardinality of set $A$. On the other hand, the probability of not finding a reservoir given that $B_{j}$ cells have evidence $j$ is $P\left(\overline{O c} / B_{j}\right)=\frac{\left|B_{j} \cap \overline{O c}\right|}{\left|B_{j}\right|}$. The conditional probabilities that a reservoir is found or not, given that $B_{j}$ is absent, are similarly calculated as

$P\left(O c / \overline{B_{j}}\right)=\frac{\left|\overline{B_{j}} \cap O c\right|}{\overline{\left|B_{j}\right|}}$ and $P\left(\overline{O c} / \overline{B_{j}}\right)=\frac{\left|\overline{B_{j}} \cap \overline{O c}\right|}{\overline{\left|B_{j}\right|}}$.

Bayes' theorem yields that,

$$
\begin{aligned}
& P\left(O c / B_{j}\right)=\frac{P\left(B_{j} / O c\right) P(O c)}{\left(P\left(B_{j}\right)\right.} \\
& P\left(O c /\left(\overline{B_{j}}\right)=\frac{P\left(\overline{B_{j}} / O c\right) P(O c)}{P\left(\overline{B_{j}}\right)}\right.
\end{aligned}
$$

The contributing value of prediction for each evidence $J$ is its weights value, defined as:

$$
\begin{gathered}
W_{j}^{+}=\frac{P\left(B_{j} / O c\right)}{P\left(B_{j} / \overline{O c}\right)} \\
W_{j}^{-}=\frac{P\left(\overline{B_{j}} / O c\right)}{P\left(\overline{B_{j}} / \overline{O c}\right)}
\end{gathered}
$$

For each evidence, $W+$ and $W$ - indicate, respectively, the weight value of existent and non-existent evidence $J$ as a measure of importance of its presence for the $D$ occurrences of reservoir represented in the posteriori probability map, as represented in Figure 1.

Another concept used is the odds ratio

$$
O(O c)=\frac{P(O c)}{1-P(O c)}=\frac{D}{T-D},
$$

which is defined as a ratio of the probability that an event will occur to the probability that an event will not occur. As to the evidence $J$, its odd is $O(O c / B j)=O(O c) \cdot \frac{P(O c / B j)}{P(\overline{O c} / B j)}$. It is these values that ultimately define the favorability of each cell, which appears in the favorability map. If more than one evidence is present, Equation (5) defines the posteriori probability log, where $n$ is the number of evidences considered:

$$
\begin{aligned}
& \log \left(O\left(O c \mid B_{1}, B_{2} \cdots B_{n}\right)\right) \\
& =\sum_{j=1}^{n} W_{j}^{+}+\log (O(O c))
\end{aligned}
$$

\section{CASE STUDY IN SERGIPE-ALAGOAS BASIN}

The Sergipe-Alagoas basin is located in the northeast of Brazil and its area is around $46.000 \mathrm{~km}^{2}$ in its largest emerged part (Loureiro, 2013). To the North, it is limited by the Pernambuco/Paraíba basin by means of the Alto de Maragogi; to the South, the emerged part is limited by the Estância platform and, in the ocean, it is limited by the Jacuípe basin, by means of the Vaza-Barris fault system. It presents a large variety of confirmed hydrocarbon accumulation models, with petroleum and natural gas production.

\section{Tectonostratigraphic Evolution}

The Sergipe-Alagoas basin has the most complete stratigraphic sequence of the Brazilian east continental margin. According to Feijó (1994a), Moriak et al. (1997, 1998), Azambuja Filho et al. (1998) and Souza-Lima et al. (2002), the Sergipe-Alagoas basin presents five tectonossequences: syneclise, pre-rift, rift, transgressive drift and regressive drift.

According to Moraes Rego (1933), the basin bedrock belongs to the Proterozoic Eon and it is composed by low-grade metamorphic rocks of the Miaba and Vaza-Barris Groups in the Sergipe sub-basin.

The first tectonossequence was deposited during the $\mathrm{Pa}$ leozoic syneclise. In this period, represented by the PermoCarboniferous sediments, the Batinga Formation and the Aracaré Formation were deposited. The Batinga Formation encompasses the following members: Mulungu, formed by conglomerates and 

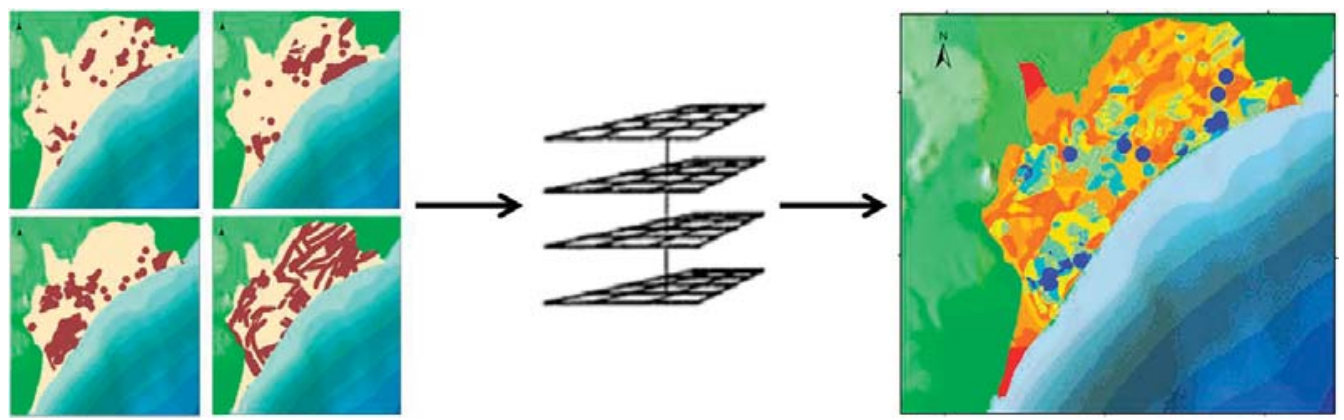

Figure 1 - Exploratory favorability map of Sergipe-Alagoas basin.

diamictites; Atalaia, formed by sandstones; and Boacica, composed of siltites and shales. The Aracaré Formation was deposited in a desertic and deltaic environment, under eolic and wave reworking (Campos Neto et al., 2007), and it comprises black shales covered by sandstones, calcarenites associated with silex and algae mudstone. Its total organic carbon (TOC) varies between 2 and 5\% (Cruz, 1994a).

The second tectonossequence, the pre-rift, is marked by the alternance between fluvial and lacustric environments of the Early Jurassic Candeeiro and Bananeiras Formations. Sandstones and reddish siltites characterize the Candeeiro Formation, and the Bananeira Formation is marked by violet red shales, easily weathered.

The third tectonossequence, the rift, occurred from Berriasian up to Aptian. In the beginning of the rift phase, there was a progressive subsidence of the basin, with high pluviosity and erosion decrease in the source areas, in the distal portions of a fluvial system grading for lacustric deltaic fronts of the Serraria Formation, composed by coarse-grained to conglomerate sandstones. In this work, this formation was extracted from the pre-rift phase, as it is used in the stratigraphic chart developed by Campos Neto et al. (2007), and was added to the rift phase and to the Coruripe Group, like the other formations of the rift phase.

Also, in the continental environment of fresh or salty water, in a lagoon context, intercalations of underlapping sandstones and shales of Barra de Itiúba Formation were deposited. At the same time, the Penedo Formation was deposited from deltaic front to prodelta environments and it is composed by fine to coarsegrained sandstones that are locally conglomeratic, well to poorly sorted with subordinate intercalations of shales and siltites.

In the period that occurred from Valanginian to Aptian, a depositional system of this unit was formed. It is interpreted as alluvial fans associated with the border faults of the basin, actives on the Aratu to Jiquiá stages (Feijó, 1994a). It is called Rio Pitanga
Formation and is characterized by large conglomeratic wedge adjacent to the large border faults of the Sergipe sub-basin. Above the Jiquiá unconformity, short duration deltaic fans were developed near to lakes in Early Aptian (Cruz \& Abreu, 1984). They were the responsible elements for the deposit of the sediments of the Coqueiro Seco Formation. This formation is marked by the alternance of sandstones, shales and siltites, and presents, in its bottom part, calcilutites and coquinas (Morro do Chaves Member) intercalated with conglomerates, sandstones and black shales.

The Maceió Formation is composed by intercalations of fine to coarse-grained arkoses which are locally conglomeratic, light gray to light yellow and brown, with greenish or dark gray shales and, to some extent, bituminous. In addition, interlaminations of anhydrite and dolomite may subordinately occur, besides the halite layers. The latter ones are informally called "Paripueira evaporites". Probably, there is a correlation between the deposits developed with the alternance between the phases of humid and arid climate. In the humid period, there would be a larger siliciclastic supply from the continent, as a result of the floods in the lake, favoring the deposition of proximal deltaic fans and subaqueous turbiditic fans, with wooden organic matter, in the lake. During all Aptian, in the dryer periods, the siliciclastic inflow would be smaller, originating shales and calcilutites with algal mats, with high content of amorphous organic matter (up to 17\%). The evaporites of this unit would have been deposited during the extreme dry periods (Arienti, 1996).

In the Late Aptian, there was the deposition of the Muribeca Formation which presents geologic layers very diversified, being directly related to the lithofacies and each one of its members, as a result of the very peculiar variations of the depositional systems. The Carmópolis Member contains polimitic conglomerates, diamictites, conglomeratic sandstones, sandstones, ritmites, calcilutites and shales. The Ibura Member comprises the largest part of the evaporitic section of the Muribeca Formation. It is 
composed by many evaporitic cycles, which began by the deposition of carbonates and sulphates (anhydrite), followed by the precipitation of halite and mixed deposits of halite-sylvite, called sylvinite. Some cycles evolved into extreme dry conditions, depositing rare and extremely soluble salts, like carnallite and taquidrite. The Oiteirinhos Member is composed by the alternance of shales and peloidal calcilutites or microbial limestones. Its origin is interpreted as being related to the marine sediments deposited in the less constrained portions, external to the evaporitic basin.

After, Feijó (1979) proposed its update to a group, adding in it the Poção, Maceió and Muribeca Formations. So, the lithostratigraphic units corresponding to the Rift and Transitional stages of the basin were included in the Coruripe Group. After this, in the Late Alagoas, there were a strong tectonism and delimitation of the hinge line (Campos Neto et al., 2007).

The Maceió and Muribeca Formations determine the end of the rift tectonossequence and are characterized by the first expressive marine incursions, which represent the definitive break-up of Africa and South America, where the first evaporitic deposits occur.

The fourth tectonossequence is the transgressive drift and it comprises all units deposited due to thermal subsidence and sedimentary overbunden. Cotinguiba and Piaçabuçu are the formations deposited in this phase, from the end of Aptian up to Coniacian. The Sergipe Group base establishes the beginning of the Drift stage in the Sergipe sub-basin, with the implementation of the carbonatic platform systems that mark the Brazilian Atlantic Margin.

The three members that compose the Riachuelo Formation represent different depositional contexts that integrate themselves to compose a wide mixed carbonatic platform. Being so, the geologic layer variations that occur inside this platform by the proximal and distal positioning are much more reflected by these units: the Maruim and Taquari Members respectively.

The Maruim Member is represented by normally thick strata, composed by calcarenites (grainstones to packstones), mainly oncolitic, locally presenting bioclastic, peloidal or oolitic composition; in some cases, the carbonatic banks are represented by the calcirudites.

The Cotinguiba Formation is composed of only the Aracaju Member, which is represented by argillites and/or gray to green, calciferous, fossiliferous siltites, with intercalations of brown, bituminous shales and yellow crypto-crystaline limestones (Bengtson, 1983).

The fifth tectonossequence is the regressive drift, which occurred from Santonian to Recent, and is represented by the
Piaçabuçu Group. It holds the Marituba, Mosqueiro, Calumbi and Barreiras Formations. Locally dolomitized, the first formation deposited, the Marituba, is mainly composed by medium to coarse-grained conglomeratic sandstones, with intercalations of bioclastic calcarenites, sandy calcarenites and shales. It is supposed that the genesis of this unit is related to the coastal deposits distributed from Campanian to Recent. In the case of Mosqueiro Formation, it is mainly composed by bioclastic gray calcarenites. Shells of foraminifera and molluscs dominate the bioclasts. Thin intercalations of shales and coarse-grained sandstones are casually found. This unit represents the carbonatic platform, which was active from Paleocene to Holocene in the Sergipe sub-basin (Feijó, 1994a). Then, the deposits of the Calumbi Formation, supposed to have been generated in the platform region, are essentially represented by shales and argilites, with some intercalations of siltites. Relatively narrow bodies of fine to very fine-grained sandstones sporadically occur intercalated between shales and siltites; they are light yellowish brown coloured and very bioturbated. These sandstones were interpreted as resulting from the reworking of sandbars by the action of waves, that experience sea floor spreading, in more distal areas of the platform (Souza-Lima, 2001a). Finally, the Barreiras Formation (from Miocene to Recent) is mainly marked by sandstones, whose granulometry varies from fine to very coarse, ortoconglomerates and, secondarily, argilites and oxidized shales.

In this article, the study area focuses on the onshore portion of the Sergipe sub-basin. Since it is a mature basin, there is abundant information and, hence, geological knowledge. Figure $2 \mathrm{~A}$ shows the stratigraphic chart with tecnossequences used in this study and Figure 2B shows the schematic section of the basin.

\section{Petroleum System}

Three main units represent the source rocks: Barra de Itiúba Formation, Coqueiro Seco and Aptian Maceió. The main source rocks of the basin are black shales, marls and calcilutites of the Maceió Formation. The average value of total organic carbon of the shales is $3.5 \%$, reaching up to $12 \%$. The average thickness of this unit is $200 \mathrm{~m}$, reaching up to $700 \mathrm{~m}$. Other important sources are the lacustrine shales of the rift phase, with possible marine influence, of the Coqueiro Seco Formation, and the lacustrine shales of the pre-rift and rift phases of the Barra de Itiuba Formation.

With regards to the reservoir rocks, the main reservoirs are in the clastic sediments of the Carmópolis Member of the Muribeca Formation. Also, there are sandstones presenting optimal porosity in the Cretaceous turbidites of the Calumbi Formation. Accumulations are found in the fractured basement and in the reservoirs of the rift phase - the porous and fractured carbonates of 


\section{A. PARCIAL STRATIGRAPHY CHART OF SERGIPE SUB-BASIN}

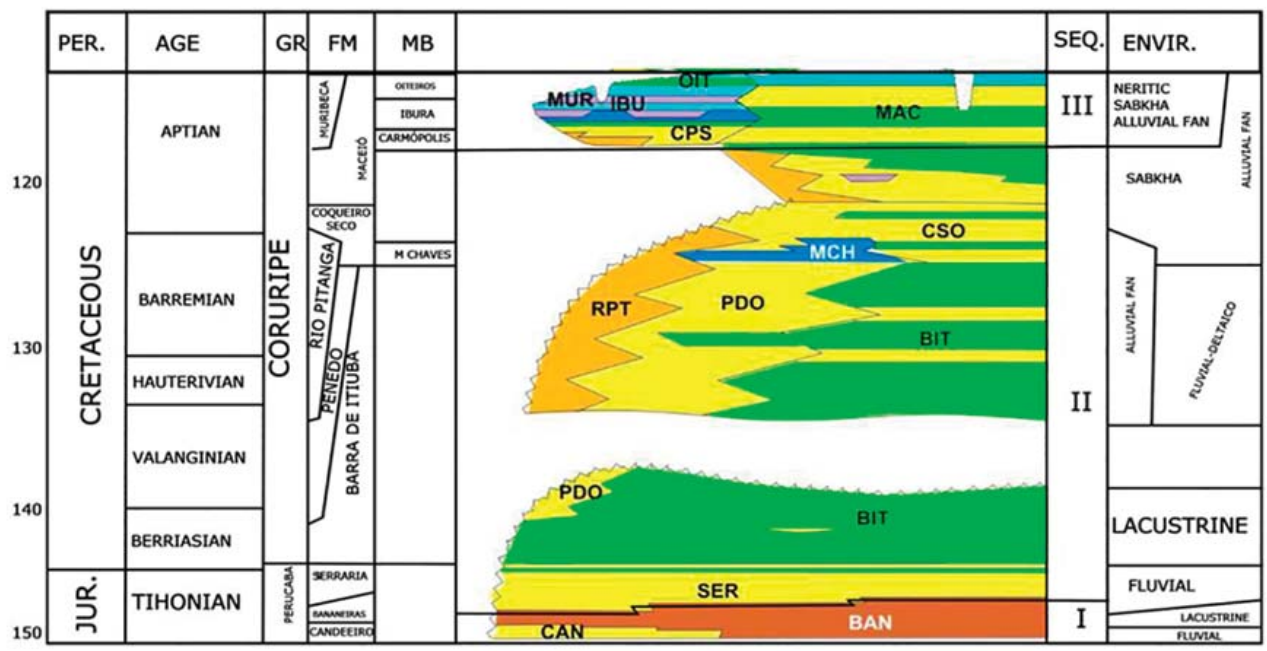

ANALYZED TECNOSSEQUENCES

I. Pre-Rift Sequence(SEQ-Pre-Ri)

II. Indivisible Rift Sequence (SEQ-Ri)

III. Rift Sequence 5 (SEQ-R5)

\section{B. SECTIONS SCHEMATIC}

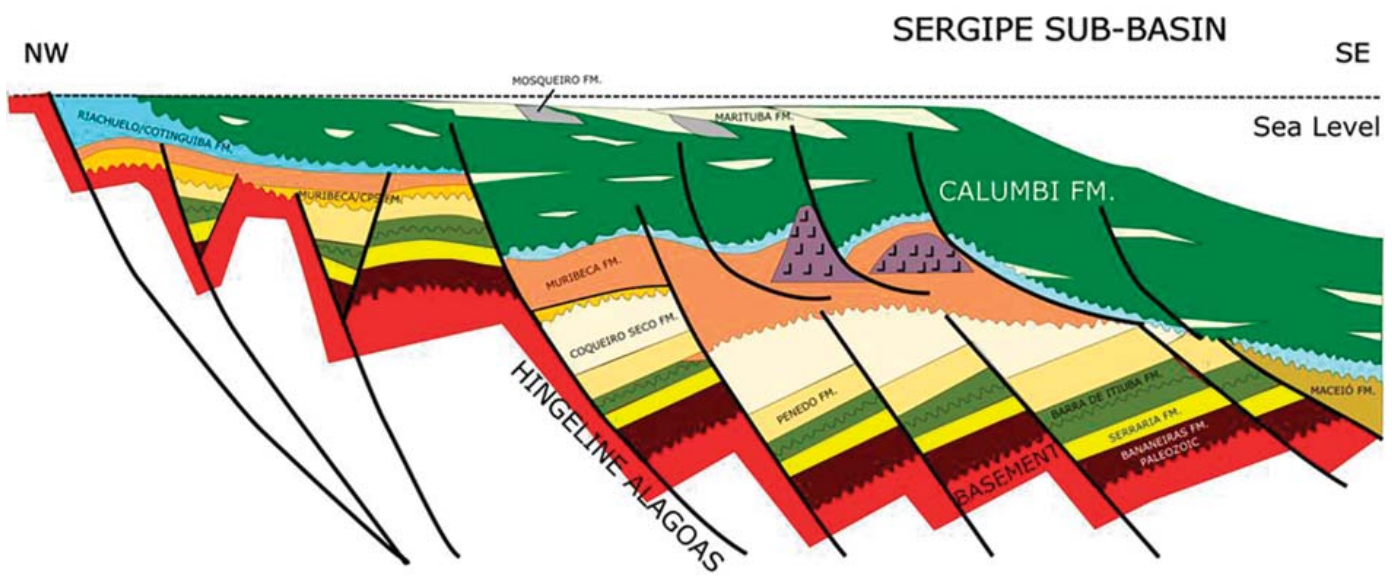

Figure 2 - Stratigraphy presented in the Sergipe sub-basin in the Sergipe-Alagoas basin: (a) Detail extracted from the Stratigraphic chart of the Sergipe sub-basin of the Sergipe-Alagoas basin (Feijó, 1994; Mohriak et al., 1997; Souza-Lima et al., 2002; UFRN, 2008), of the sequences that will be used in the study and (b) Geological schematic section of the Sergipe sub-basin.

the Riachuelo and Cotinguiba Formations. In the deep marine part of the Sergipe sub-basin, the main reservoirs are the Cretaceous and Tertiary turbidites of the Calumbi Formation, and, secondarily, the reservoirs of the transitional sequence. In the emerged part of the Sergipe sub-basin, the main reservoirs are the sandstones of the Serraria, Barra de Itiúba, Penedo, Coqueiro Seco and Maceió Formations. In the deep marine part, the main reservoirs are the Cretaceous and Tertiary turbidites of the Calumbi Formation, and, secondarily, the clastic reservoirs of the Maceió Formation.

Studies reveal that the development started in Aptian (115 Ma.) and, for shallow accumulations that exist in the emerged part of the Sergipe sub-basin, the development is assigned to the Maceió Formation, which is in maturation in the 
bottom part of the Alagoas hinge. The migration occurred from this point by common faults, that compose the Alagoas hinge, up to Carmópolis Member, capped by the shales and evaporites of the Ibura Member of the Muribeca Formation. The latter acted as the carrier layer of petroleum up to its final acumulation in traps, usually paleogeomorphic. The largest field of the basin, Carmópolis, with 268 million cubic meters of in situ original oil, was supplied by this source with long-distance lateral migration. The gravitational (listric) and common faults played an important role. During the rifting of the basin, they were active and, moreover, they worked like pipelines for hydrocarbon migration.

The traps, researched in the pre-rift and rift sequences, are dome structures, like the Pilar and São Miguel dos Campos Fields. In the transitional sequence, the traps related to the Muribeca Formation/Carmópolis Member are mainly paleogeomorphic. In the sandstones of the Maceió Formation, the existent traps are fault blocks, or associated with halokinesis. In the upper sequence, the main reservoirs are the Cretaceous and Tertiary turbidites of the Calumbi Formation, the traps are mixed and stratigraphic, associated with the troughs and warpings caused by the salt tectonics or by the channel fill, sometimes controlled by basement reactivated faults.

\section{Dataset and Variables}

The selection of variables that have useful information to distinguish potentially productive areas is a crucial step for the geologic risk assessment. This study considered the maps hereinafter presented (UFRN, 2008) for the proposition of the evidences for the Sergipe sub-basin.

The Sergipe sub-basin has 4,583 drilled wells, of which 992 are for exploration and 3,591 for the production development (482 drilled offshore, 4,101 onshore); the Alagoas sub-basin has 910 drilled wells, of which 385 were drilled for exploration and 525 for petroleum production (864 onshore, 46 offshore) (BDEPWEBMAPS, 2014). The hydrocarbon occurrences were defined from well reclassification data, and 715 exploratory wells were considered to be points with known hydrocarbon reservoirs.

The maps presented from Figure 3 to 7 were based on integration of the seismic (interpretations of seismic sections) and gravimetric (correlation between the gravimetric signal and high levels of basement or volcanic structure) data with the well data (conversion of in depth seismic maps from checkshot profiles, using time $\times$ depth curves).

The methodology was applied based on geological criteria, as follows: presence of reservoir rocks and seal elements of petroleum systems, presence of large amounts of sediment, structural highs and faults. The presence reservoir rocks and seal can be evidenced by thicker regions tecnossequences shown in Figures 3, 4 and 5. The pre-rift, indivisible and rift tecnossequences were chosen because they have representative rocks regarding the main plays in onshore Sergipe sub-basin. The bouguer anomaly values presented on Figure 6 were considered to identify regions according with to its sedimentary thickness. Regarding structural high, the top of the crystalline basement were considered on Figure 7 , since there may anticline structures nearby. Lastly, the faults were considered due to its possible contribuition to hydrocarbon migration to the reservoir.

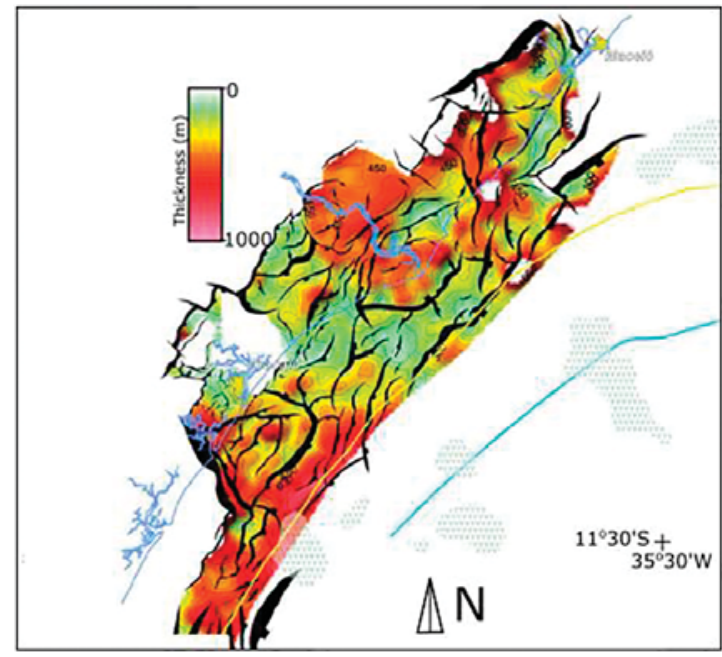

Figure 3 - Seismic structure and isopach map of the Pre-rift tectonossequence.

The thickness were estimated in each isopach considering interpolated information for each horizon based on krigging mathematical models, in which the isopach map was acquired from the difference between two in depth consecutive structural maps.

The analysis carried out by the model considered the data obtained from 487 exploratory wells with discoveries (BDEPWEBMAPS, 2014) for the evaluation of the evidences analyzed from the maps presented in Figure 3 to 7 . The wells that presented discoveries in the sedimentary layers were properly taken into account in the proposed evidences, with an arbitrated influence area of $2.5 \mathrm{~km}$. Table 1 presents the proposed evidences and the adopted criteria, together with the area and number of exploratory wells presenting hydrocarbon discovery (D) for each analyzed evidence.

We implemented the weights of evidence model supported by a georeferenced structured database, developed specifically for this purpose.

The exploratory evidences were considered in georreferenced discretized binary layers, generated from maps presented in Figures 3 to 7 . Those layers were created based on criterias presented in Table 1 and presented in Figure 8. 


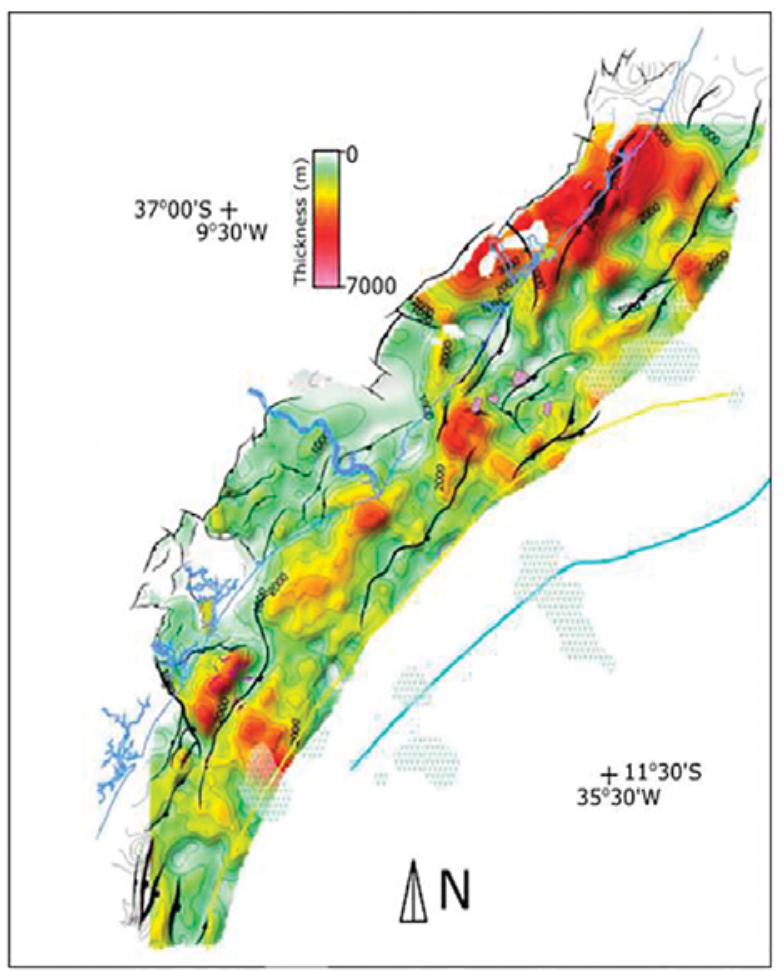

Figure 4 - Seismic structure and isopach map of the Indivisible tectonossequence.

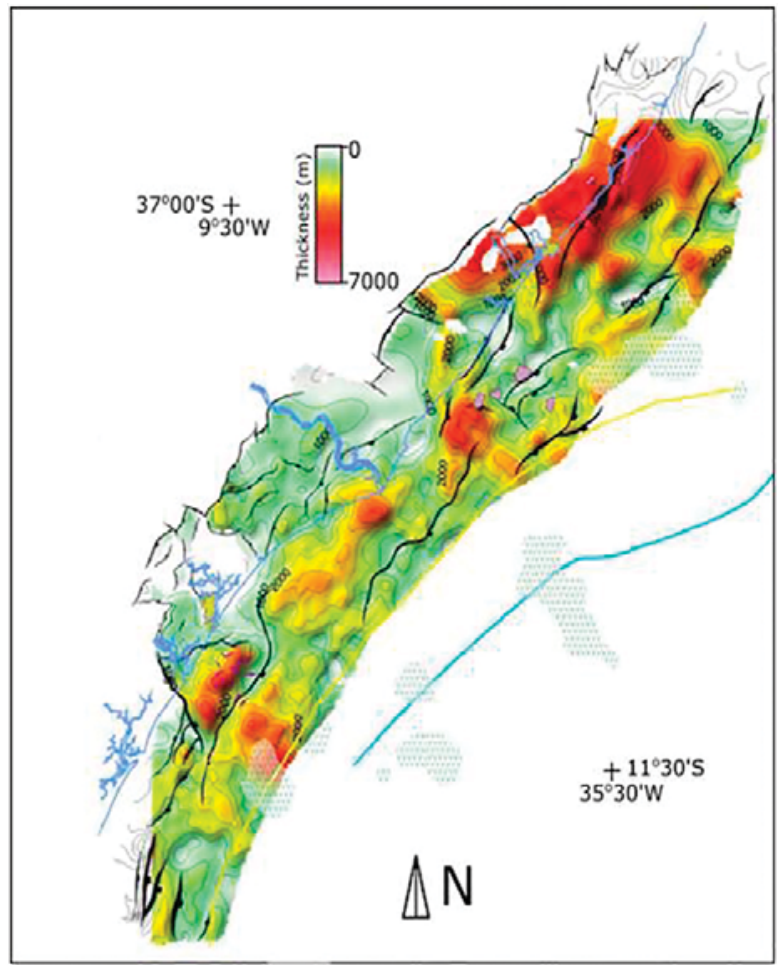

Figure $\mathbf{5}$ - Seismic structure and isopach map of the Rift tectonossequence. 


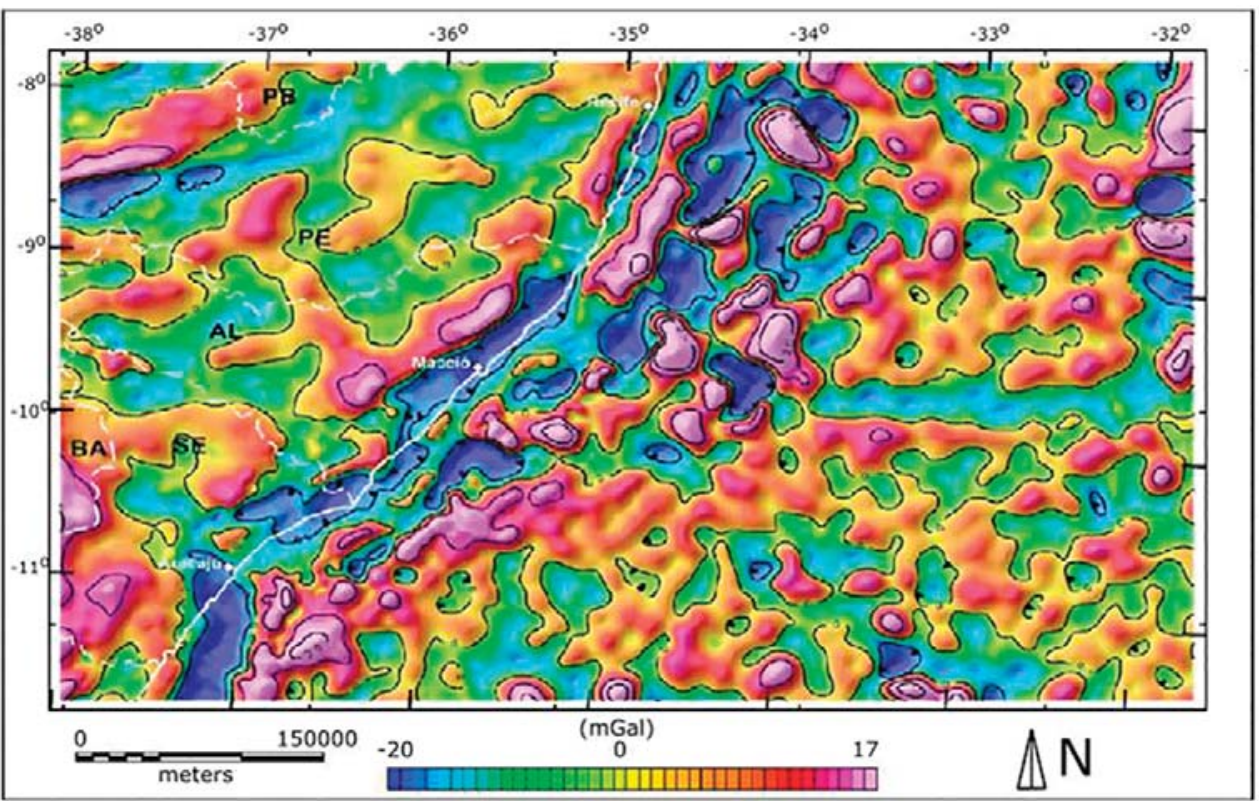

Figure 6 - Residual Bouguer Anomaly Map (the white line is the coast line). This map was generated from band pass between 10 and $100 \mathrm{~km}$.

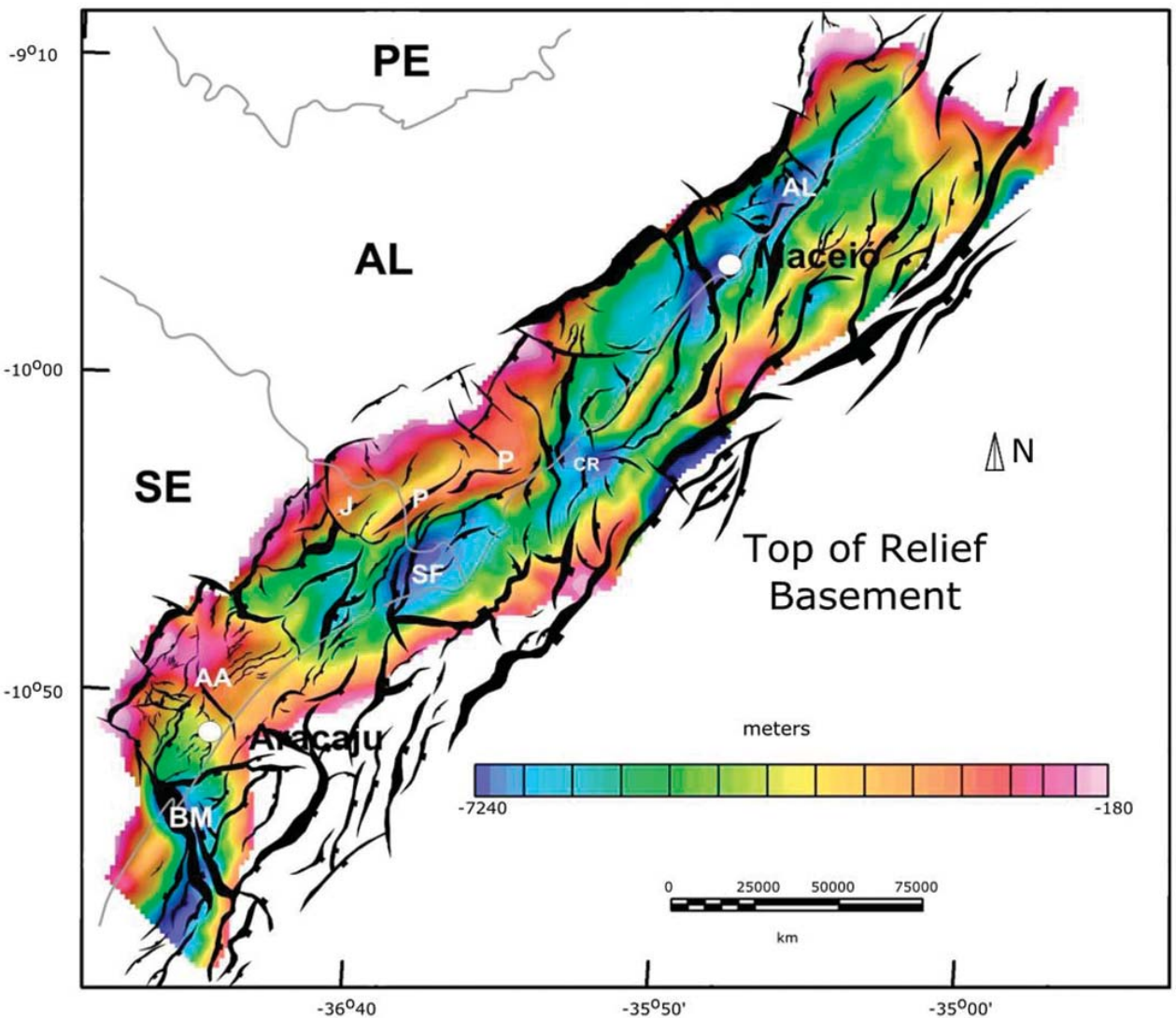

Figure 7 - Basement faults interpreted from seismic lines and crystalline basement upper part relief. 
Table 1 - Exploratory evidences.

\begin{tabular}{|c|c|c|c|c|}
\hline$B_{j}$ & Evidence & Criteria & Area $\left(\mathrm{km}^{2}\right)$ & $D$ \\
\hline 1 & Pre-rift & Thickness $>160 \mathrm{~m}$ & 810.72 & 182 \\
2 & Indivisa rift & Thickness $>160 \mathrm{~m}$ & 1141.03 & 230 \\
3 & 5 th Rift & Thickness $>160 \mathrm{~m}$ & 1422.96 & 452 \\
4 & Positive Bouguer & $\mathrm{mGal}>0$ & 2709.00 & 58 \\
5 & Negative Bouguer & $\mathrm{mGal}<0$ & 2172.15 & 428 \\
6 & Basement faults & Buffer $1,500 \mathrm{~m}$ & 2622.01 & 335 \\
\hline
\end{tabular}
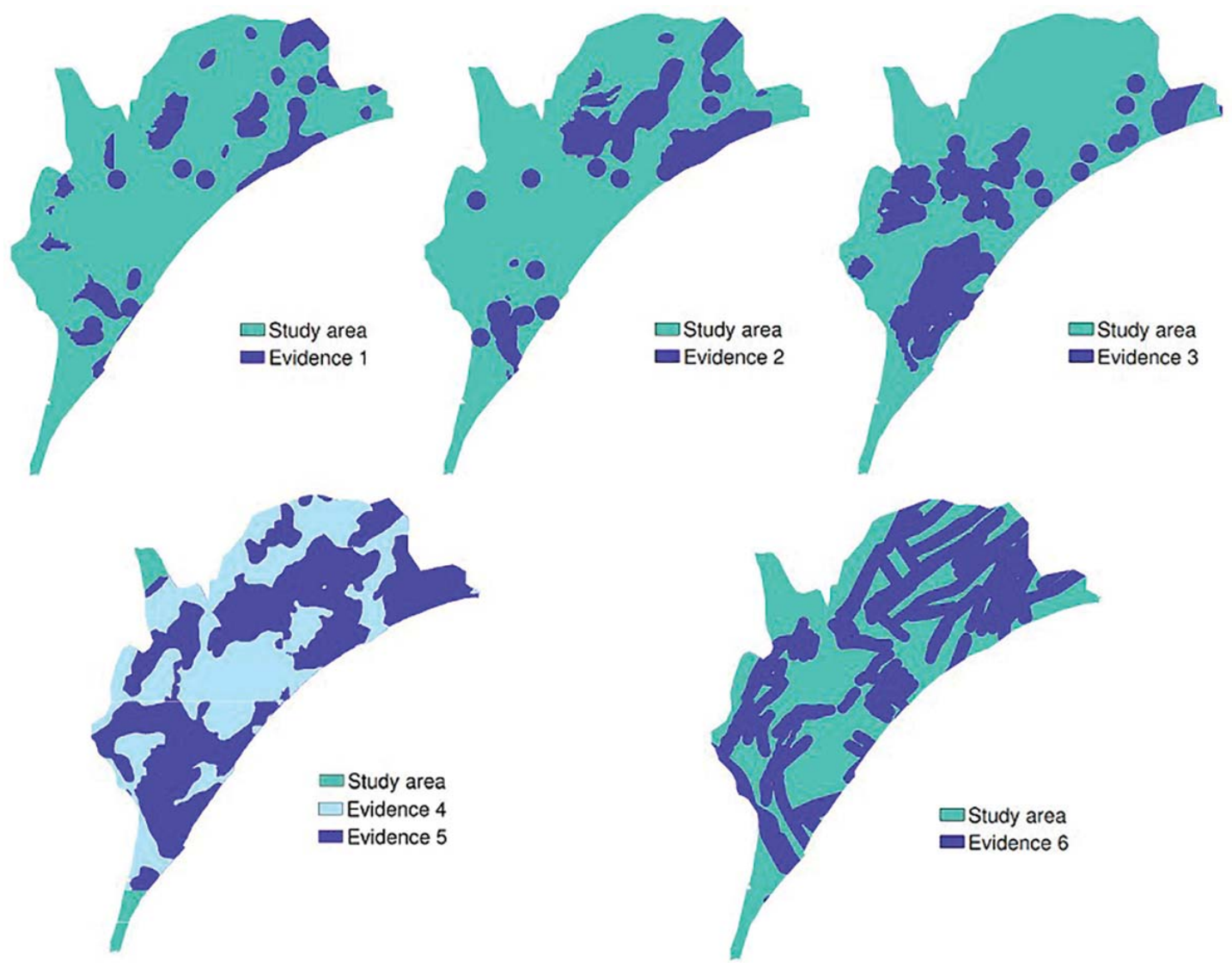

Figure 8 - Exploratory evidences.

\section{RESULTS}

The results obtained by the applied methodology is presented here in two steps: calculus of the weights and generation of the posteriori favorability maps.

The calculi of the weights were carried out for each evidence with respect to the portion of the wells used for the favorability evaluation. The presented maps were produced by the sum of the posteriori probability log for each considered evidence, as presented by Equation (5), Section 2 (methodology). The study considered the evidences that showed $W+$ with a value over 1.20 (or $\log (W+)>0.2$ ) in the proposition of the exploratory favorability map, so $B_{j}=5$ was not considered. The obtained values by the probability a posteriori from considered $B_{j}$ maps were summed and presented in color scale where blue color represents the most favorable result and red color represents the most unfavorable results.

To validade the proposed model, the evidences were evaluted with the 70\% first discoveries (342 of 487 exploratory wells). The obtained weights for $70 \%$ first discoveries are shown in Table 2 and Figure 9. 
Table 2 - Weights of evidences calculated for the exploratory evidence evaluation in Sergipe-Alagoas basin with 70\%.

\begin{tabular}{|c|c|c|c|}
\hline$B_{j}$ & Evidence & $W+$ & $\log (W+)$ \\
\hline 1 & Pre-rift & 2.48 & 0.91 \\
2 & Indivisa rift & 2.18 & 0.78 \\
3 & 5th Rift & 3.32 & 1.20 \\
4 & Positive Bouguer & 1.92 & 0.65 \\
5 & Negative Bouguer & 0.21 & -1.55 \\
6 & Basement faults & 1.31 & 0.27 \\
\hline
\end{tabular}

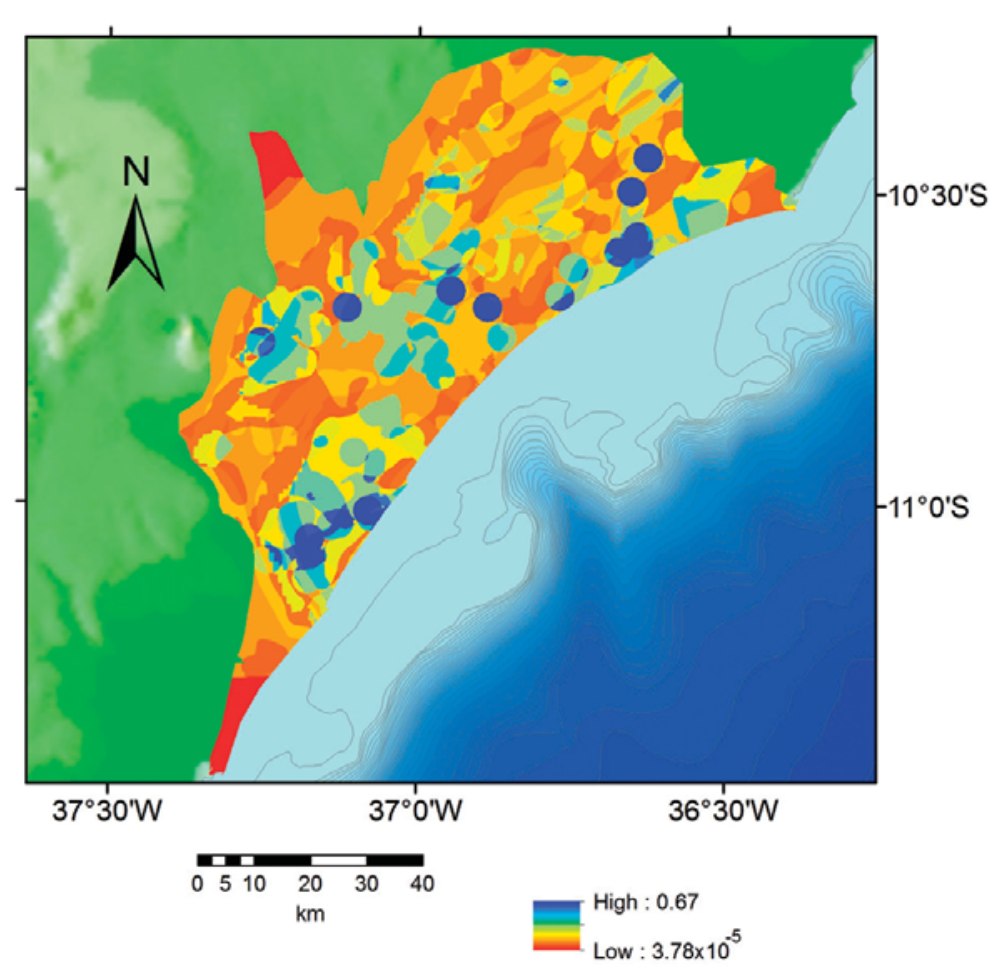

Figure 9 - Exploratory favorability map of Sergipe-Alagoas basin with 70\% first discoveries.

The favorability areas presented in Figure 8 were compared to the remaining 145 exploratory wells with discoveries drilled (30\%). The results presented in Figure 10 confirm the tendency of discoveries concentration in most favorable areas, standatizated in 1-100 scale, where 100 represents the most favorable. In particular, note that $67 \%$ of discoveries are situated in the $64 \%$ superior level of favorability appointed by the model.

The results found using the WOFE model show that the proposed evidences are compliant with the data from the considered exploratory wells that present discoveries, and the methodology proved adequate. The final weights calculated for SergipeAlagoas basin, now considering $100 \%$ of data, are presented in Table 3 and Figure 10, respectively.
To clarify the application of the method, the values obtained by the model application are presented as follows. The study area of $t=5,006.35 \mathrm{~km}^{2}$ was discretized in $T=500,635$ cells, which has $D=487$ exploration wells drilled with discoveries. The prior probability that a randomly chosen cell presents a discovery in the study area results in $P(O c)=\frac{D}{T}=9.73^{\star} 10 \mathrm{E}-05$.

The evidence $J=1$ (Pre-rift) was considered with area of $810.72 \mathrm{~km}^{2}$ (discretized in $B_{1}=81,072$ cells) and $O c=182$ discovery cells. By applying the Equation (1) with respect to the probability of selecting a cell with the occurrence of reservoir given that evidence 1 is present, the value of $P\left(O c / B_{j}\right)=$ $\frac{P\left(B_{j} / O c\right) P(O c)}{P\left(B_{j}\right)}=0.37$. In a similar way, Equation (2) allows us to calculate the probability of not finding a reservoir given that 


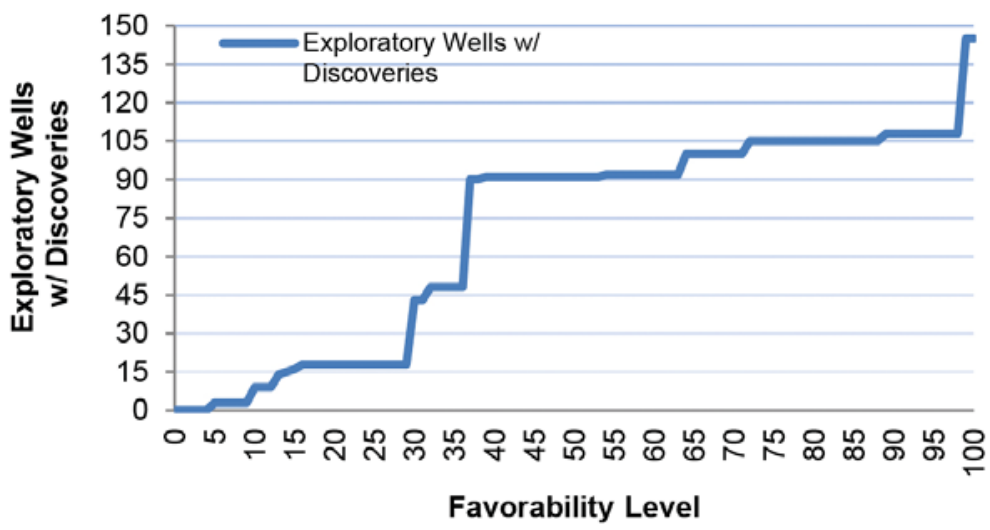

Figure 10 - Evaluation of exploratory map with $70 \%$ first discoveries.

Table 3 - Weights of evidences for Sergipe-Alagoas basin.

\begin{tabular}{|c|c|c|c|}
\hline$B_{j}$ & Evidence & $W+$ & $\log (W+)$ \\
\hline 1 & Pre-rift & 2.31 & 0.83 \\
2 & Indivisa rift & 2.08 & 0.73 \\
3 & 5th Rift & 3.28 & 1.18 \\
4 & Positive Bouguer & 2.03 & 0.71 \\
5 & Negative Bouguer & 0.22 & -1.51 \\
6 & Basementfaults & 1.31 & 0.27 \\
\hline
\end{tabular}

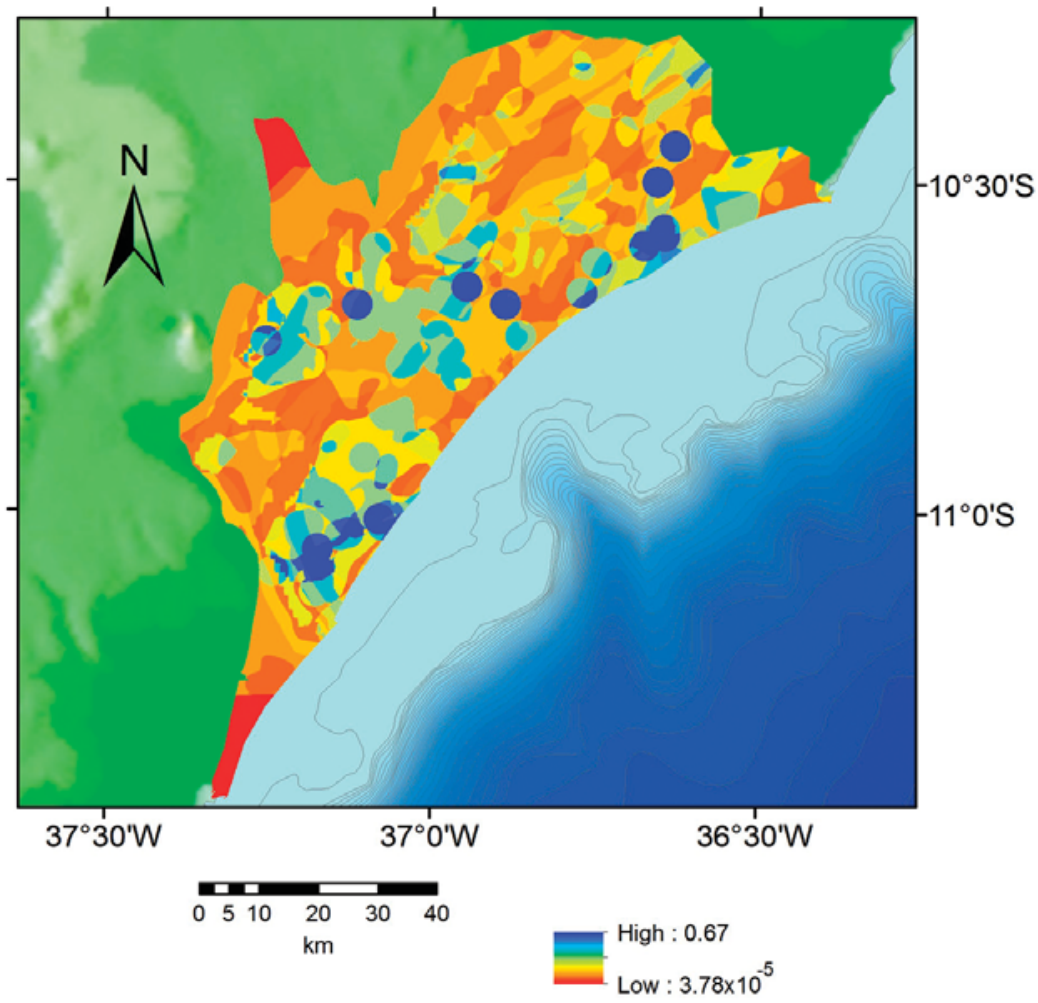

Figure 11 - Exploratory favorability map of Sergipe-Alagoas basin. 
evidence 1 is present is

$$
P\left(O c /\left(\overline{B_{j}}\right)\right)=\frac{P\left(\overline{B_{j}} / O c\right) P(O c)}{P\left(\overline{B_{j}}\right)}=0.16 .
$$

The weighted value for evidence 1 is $W_{j}^{+}=\frac{P\left(B_{j} / O c\right)}{P\left(B_{j} / \overline{O c}\right)}=2.31$ and its natural $\log$ is 0.83 .

The favorability map sums the log value of the weight evidences calculated in the regions where they are present, together the value $\log (O(O c))=\frac{D}{T-D}=\frac{P(O c)}{P(1-O c)}=9.74^{\star} 10 \mathrm{E}-05$ in accordance with Equation (5).

\section{CONCLUSION}

We proposed the favorability evaluation of hydrocarbon evidences by means of the Weights of Evidence approach and applied this approach to the Sergipe-Alagoas basin for validation. Such a model allows one to evaluate the favorability of areas of interest in a consistent, easily updatable way. The output of the model can be used as a tool for the decision-making process concerning the exploratory acitivies.

To validate the approach, we firtly applied it to $70 \%$ of the exploratory wells in the Sergipe-Alagoas basin, to obtain a model and confront the output of this model with the $30 \%$ remaining data. The validation confirmed the tendency of discoveries to be concentrated in the most favorable areas of the favorability map. The complete output, a favorability map organizing the area of interest into different favorability levels, can help the decision-maker identify target areas for further exploration, data gathering or area relinquishment.

It is worth mentioning that the model can be easily updated with new, relevant exploratory information, especially providing from newly drilled wells. The new output can then be used to update the favorability maps, with views to reinforcing previous assessments or dismissing them, whenever necessary. We argue that proposed methodology decreases the exposure of investments to the quantified uncertainties, causing impacts on the success of the E\&P activities based on its historic results, as demonstrated in the case study of the Sergipe-Alagoas basin.

\section{ACKNOWLEDGEMENTS}

Edilson F. Arruda would like to thank Carlos Chagas Filho Foundation for Research Support of the State of Rio de Janeiro, FAPERJ, under grant no. E-26/202.789/2015, and the Brazilian national research council - CNPq, under grant no. 303543/2015-9.

\section{REFERENCES}

ABEDI M, TORABI SA, NOROUZI GH \& HAMZEH M. 2012. ELECTRE III: A knowledge-driven method for integration of geophysical data with geological and geochemical data in mineral prospectivity mapping. Journal of Applied Geophysics, 87: 9-18.

AGTERBERG FP \& BONHAM-CARTER GF. 1990. Statistical Applications in the Earth Sciences. Geological Survey of Canada.

AGTERBERG FP. 1992. Combining indicator patterns in weights of evidence modeling for resource evaluation. Nonrenewable Resources, 1(1): $39-50$.

AGTERBERG FP \& BONHAM-CARTER GF. 2005. Measuring the performance of mineral-potential maps. Natural Resources Research, 14(1): $1-17$.

ANP - Agência Nacional do Petróleo, Gás Natural e Biocombustíveis. 2014. Plano Plurianual de Geologia e Geologia e Geofísica. Available on: <http://www.anp.gov.br/?pg=58310>. Access on: June 5, 2014.

ARIENTI LM. 1996. Análise estratigráfica, estudo de fluxos gravitacionais e geometria dos depósitos Rift da Fm. Maceió e Fm. Poção - Bacia de Alagoas. Doctorate Thesis, Curso de Pós-graduação em Geociências, UFRJ, Brazil. 398 pp.

BDEP - Banco de Dados de Exploração e Produção. 2014. Banco de Dados de Exploração e Produção da Agência Nacional do Petróleo, Gás Natural e Biocombustíveis. Available on: <http://www.bdep.gov.br/> Access on: June 5, 2014.

AZAMBUJA FILHO NC, ARIENTI LM \& CRUZ FEG. 1998. Guidebook to the rift-drift Sergipe-Alagoas passive margin basin, Brazil. In: AAPG International Conference \& Exhibition, 1998, Rio de Janeiro, Brazil, AAPG/PETROBRAS, 113 pp. (Excursion Guide).

BDEP-WEBMAPS. 2014. Acervo Georreferenciado de Dados de Exploração e Produção da Agência Nacional do Petróleo, Gás Natural e Biocombustíveis. Available on: <http://maps.bdep.gov.br/website/ maps/viewer.htm>. Access on: June 5, 2014.

BENGTSON P. 1983. The Cenomanian-Coniacian of the Sergipe Basin, Brazil. Fossils and Strata, 12: 1-78.

BLAHUT J, STERLACCHINI S \& BALLABIO C. 2009. Effect of the input parameters on the spatial variability of landslide susceptibility maps derived by statistical methods. Case study of the Valtellina Valley (Italian Central Alps) [Priestorová variabilita máp náchylnosti území na vznik zosuvov. príkladová štúdia údolia valtellina (talianske centrálne alpy)]. Geograficky Casopis, 61(1): 3-18.

BLAHUT J, KLIMEŠ J \& VAŘILOVÁ Z. 2013. Quantitative rockfall hazard and risk analysis in selected municipalities of the České Švýcarsko National Park, Northwestern Czechia. Geografie, 118(3): 205-220.

BONHAM-CARTER G. 1994. Geographic information systems for geoscientists: modelling with GIS. Elsevier. 
BONHAM-CARTER GF, AGTERBERG FP \& WRIGHT DF. 1988. Integration of geological datasets for gold exploration in Nova Scotia. Digital Geologic and Geographic Information Systems, p. 15-23.

BONHAM-CARTER GF, AGTERBERG FP \& WRIGHT DF. 1990. Weights of Evidence Modelling: a new approach to mapping mineral potential. In: AGTERBERG FP \& BONHAM-CARTER GF (Eds.). Statistical Applications in the Earth Sciences. Geological Survey of Canada, Paper 89-9, p. 171-183.

BROWN WM, GEDEON TD, GROVES DI \& BARNES RG. 2000. Artificial neural networks: a new method for mineral prospectivity mapping. Australian Journal of Earth Sciences, 47(4): 757-770.

BROWN W, GROVES D \& GEDEON T. 2003. Use of fuzzy membership input layers to combine subjective geological knowledge and empirical data in a neural network method for mineral-potential mapping. Natural Resources Research, 12(3): 183-200.

CAMPOS NETO OPA, LIMA WS \& CRUZ FEG. 2007. Bacia de SergipeAlagoas. Boletim de Geociências da Petrobras, 15(2): 406-415.

CARRANZA EJM. 2011. Editorial: Geocomputation of mineral exploration targets. Computers \& Geosciences, 37(12): 1907-1916.

CARRANZA EJM \& HALE M. 2001. Geologically constrained fuzzy mapping of gold mineralization potential, Baguio district, Philippines. Natural Resources Research, 10(2): 125-136.

CARRANZA EJM \& HALE M. 2002. Spatial association of mineral occurrences and curvilinear geological features. Mathematical Geology, 34(2): 203-221.

CARRANZA EJM, VAN RUITENBEEK FJA, HECKER C, VAN DER MEIJDE $M$ \& VAN DER MEER FD. 2008. Knowledge-guided data-driven evidential belief modeling of mineral prospectivity in Cabo de Gata, SE Spain. International Journal of Applied Earth Observation and Geoinformation, 10(3): 374-387.

CASSARD D, BILLA M, LAMBERT A, PICOT JC, HUSSON Y, LASSERRE JL \& DELOR C. 2008. Gold predictivity mapping in French Guiana using an expert-guided data-driven approach based on a regional-scale GIS. Ore Geology Reviews, 34(3): 471-500.

CHENG Q \& AGTERBERG FP. 1999. Fuzzy weights of evidence method and its application in mineral potential mapping. Natural Resources Research, 8(1): 27-35.

CHENG QM, CHEN ZJ \& KHALED A. 2007. Application of fuzzy weights of evidencemethod in mineral resource assessmentfor gold in Zhenyuan district, Yunnan Province, China. Earth Science Journal of China University of Geosciences, 32(2): 175-184.

CHENG Q. 2014. Sequential weights of evidence as a machine learning model for mineral deposits prediction. Mathematics of Planet Earth, p. 157-161.

COBB H. 1960. Operations Research-A Tool in Oil Exploration. Geophysics, 25(5): 1009-1022.
CRUZ WM \& ABREU CJ. 1984. Sedimentologia da área de Pilar e adjacências. DENEST/DEPEX/PETROBRAS, Internal Report, 60 pp.

DE QUADROS, TELMO FP, KOPPE JC, STRIEDER AJ \& COSTA JF. 2006. Mineral-potential mapping: a comparison of weights-of-evidence and fuzzy methods. Natural Resources Research, 15(1): 49-65.

FElJó FJ. 1979. Estudo dos carbonatos Muribeca e Riachuelo no Alto de Aracaju - Bacia Sergipe Alagoas - Nordeste do Brasil. DIREX/RPNE/PETROBRAS, Internal Report, 27 pp.

FEIJÓ FJ. 1994A. Bacias de Sergipe e Alagoas. Boletim de Geociências da Petrobras, 8(1): 149-161.

FORD A \& HART CJR. 2013. Mineral potential mapping in frontier regions: A Mongolian case study. Ore Geology Reviews, 51: 15-26.

HARRIS D \& PAN G. 1999. Mineral favorability mapping: a comparison of artificial neural networks, logistic regression, and discriminant analysis. Natural Resources Research, 8(2): 93-109.

HARRIS JR, WILKINSON L, HEATHER K, FUMERTON S, BERNIER MA, AYER J \& DAHN R. 2001. Application of GIS processing techniques for producing mineral prospectivity maps - a case study: mesothermal Au in the Swayze Greenstone Belt, Ontario, Canada. Natural Resources Research, 10(2): 91-124.

HARRIS DP, ZURCHER L, STANLEY M, MARLOW J \& PAN G. 2003. A comparative analysis of favourability mappings by weights of evidence, probabilistic neural networks, discriminant analysis, and logistic regression. Natural Resources Research, 12: 241-255.

HE B, WANG D \& CHEN C. 2014. A novel method for mineral prospectivity mapping integrating spatial-scene similarity and weightsof-evidence. Earth Science Informatics, p. 1-17.

HRONSKY JMA \& GROVES DI. 2008. Science of targeting: definition, strategies, targeting and performance measurement. Australian Journal of Earth Sciences, 55(1): 3-12.

JORDANOV J, DARAKCHIEV I \& BELOGUSHEV V. 2006. Oil and gas resource assessment methodologies: implementation in national balance estimation and company's exploration policy. Annual of the University of Mining and Geology St. Ivan Rilski, 49(1): 103-109.

KOULI M, LOUPASAKIS C, SOUPIOS P, ROZOS D \& VALLIANATOS F. 2014. Landslide susceptibility mapping by comparing the WLC and WofE multi-criteria methods in the West Crete Island, Greece. Environmental Earth Sciences, p. 1-23.

LOUREIRO E. 2013. Bacia de Sergipe Alagoas. In: Seminário TécnicoAmbiental da $11^{\mathrm{a}}$ Rodada de Licitações de Petróleo e Gás, 2013, Rio de Janeiro, Brazil. Available on: <http://www.brasil-rounds.gov.br/ arquivos/Seminarios_11/tec_ambiental/Bacia_Sergipe-Alagoas.pdf > . Access on: June 5, 2014.

MAGALHÃES LA \& SOUZA FILHO CR. 2012. Targeting of gold deposits in Amazonian exploration frontiers using knowledge- and data-driven 
spatial modeling of geophysical, geochemical, and geological data. Surveys in Geophysics, 33(2): 211-241.

MORAES REGO LF. 1933. Notas sobre a geologia, a geomorfologia e os recursos minerais de Sergipe. Anais da Escola de Minas de Ouro Preto, 24: 31-84.

MOON WM. 1998. Integration and fusion of geological exploration data: a theoretical review of fuzzy logic approach. Geosciences Journal, 2(4): 175-183.

MOHRIAK WU, BASSETTO M \& VIEIRA IS. 1997. Observações sobre a carta estratigráfica e a evolução tectono-sedimentar das bacias de Sergipe e Alagoas. Boletim de Geociências da Petrobras, 11(1/2): 84115.

MOHRIAK WU, BASSETO M \& VIEIRA IS. 1998. Crustal architecture and tectonic evolution of the Sergipe-Alagoas and Jacuípe basins, offshore northeastern Brazil. Tectonophysics, 288: 199-220.

NAMPAK H, B PRADHAN \& MANAP MA. 2014. Application of GIS based data driven evidential belief function model to predict groundwater potential zonation. Journal of Hydrology, 513: 283-300.

NEWENDORP PD. 1972. Bayesian Analysis - A Method for Updating Risk Estimates. JPT, 24(2): 193-198. SPE 3463-PA.

PARTINGTON G. 2010. Developing models using GIS to assess geological and economic risk: An example from VMS copper gold mineral exploration in Oman. Ore Geology Reviews, 38(3): 197-207.

PAZAND K, HEZARKHANI A \& PAZAND K. 2013. Predictive mapping for porphyry copper mineralization: a comparison of knowledge-driven and data-driven fuzzy models in Siahrud area, Azarbaijan province, NW Iran. Applied Geomatics, 5(3): 215-224.

PORWAL A, CARRANZA EJM \& HALE M. 2003. Artificial neural networks for mineral-potential mapping: a case study from Aravalli Province, Western India. Natural Resources Research, 12(3): 155-171.

PORWAL A, CARRANZA EJM \& HALE M. 2004. A hybrid neuro-fuzzy model for mineral potential mapping. Mathematical Geology,36(7): 803826.

PORWAL A, CARRANZA EJM \& HALE M. 2006. Bayesian network classifiers for mineral potential mapping. Computers \& Geosciences, 32(1): $1-16$.

POURTAGHI ZS \& POURGHASEMI HR. 2014. GIS-based groundwater spring potential assessment and mapping in the Birjand Township, southern Khorasan Province, Iran. Hydrogeology Journal, 22(3): 643662.

REGMI AD, DEVKOTA KC, YOSHIDA K, PRADHAN B, POURGHASEMI HR, KUMAMOTO T \& AKGUN A. 2014. Application of frequency ratio, statistical index, and weights-of-evidence models and their comparison in landslide susceptibility mapping in Central Nepal Himalaya. Arabian Journal of Geosciences, 7(2): 725-742.

ROSTIROLLA SP. 1997. Alguns aspectos da avaliação de favorabilidade em geologia exploratória. Brazilian Journal of Geology, 27(4): 327-338.

ROSTIROLLA SP, MATTANA AC \& BARTOSZECK MK. 2003. Bayesian assessment of favorability for oil and gas prospects over the Recôncavo basin, Brazil. AAPG Bulletin, 87(4): 647-666.

SATO EN, DE ALMEIDA TIR, DIAS VM, YAMAMOTO JK, CAVALLARO DAF \& SANTANA WRR. 2013. Index and probability maps of occurrence of iron ore deposits: a proposed geophysical approach developed in Curral Novo do Piauí (PI) State - Brazil. Brazilian Journal of Geophysics, 31(3): 365-374.

SINGER DA \& KOUDA R. 1999. A comparison of weights-of-evidence methods and probabilistic neural networks: Natural Resources Research, 8(4): 287-298.

SILVA EC, SILVA AM, TOLEDO CLB, MOL AG, OTTERMAN DW \& DE SOUZA SRC. 2012. Mineral Potential Mapping for Orogenic Gold Deposits in the Rio Maria Granite Greenstone Terrane, Southeastern Pará State, Brazil. Economic Geology, 107(7): 1387-1402.

SOUZA-LIMA W. 2001A. Macrofaunas campanianase ambientes deposicionais da Formação Calumbi, bacia de Sergipe-Alagoas, Brasil. Doctorate Thesis, Programa de Pós-Graduação em Geologia, UFRJ, Brazil, $366 \mathrm{pp}$.

SOUZA-LIMA W, ANDRADE EJ, BENGTSWON P \& GALM PC. 2002. A Bacia de Sergipe-Alagoas: evolução geológica, estratigrafia e conteúdo fóssil. Fundação Paleontológica Phoenix, 34 pp.

UFRN - Universidade Federal do Rio Grande do Norte. 2008. Revisão Geológica e Reavaliação dos Sistemas Petrolíferos da Bacia de SergipeAlagoas. Study Report.

VIDAL AC, ROSTIROLLA SP \& KIANG CH. 2005. Análise de favorabilidade para a exploração de água subterrânea na região do Médio Tietê, Estado de São Paulo. Brazilian Journal of Geology, 35(4): 475-481.

WENHUI D, GONGWEN W, YONGQING C, NANA G, YINGLONG H \& PENGFEI Z. 2014. Information Extraction and Interpretation Analysis of Mineral Potential Targets based on ETM+ Data and GIS Technology: A Case Study of Copper and Gold Mineralization in Burma. In: IOP Conference Series: Earth and Environmental Science. IOP Publishing.

ZHANG D, AGTERBERG F, CHENG Q \& ZUO R. 2013. A comparison of modified fuzzy weights of evidence, fuzzy weights of evidence, and logistic regression for mapping mineral prospectivity. Mathematical Geosciences, 46(7): 869-885. 